\title{
Regional Economics: How does Tourism Influence Regional Revenue of Malang Raya?
}

\author{
Elok Tri Wahyuni*, Susilo, Sri Muljaningsih \\ Faculty of Economics and Business, University of Brawijaya, Malang, Indonesia
}

\begin{abstract}
This paper aims to analyze the influence of tourism sector to regional revenue of Malang Raya. In this case, tourism sector used the number of tourist arrival, hotel's room occupancy rate, the number of restaurants, and the sum of PDRB (Gross Regional Domestic Product) during the period of 2006-2016. The secondary panel data from three Local Governments in Malang Raya is analyzed by using fixed effect model of multiple regressions. The result shows that all independent variables simultaneously give significant influence to regional revenue. Partially, the number of tourist arrival and hotel's room occupancy rate give the significant influence to regional revenue. The other two variables, i.e. the number of restaurant and sum of PDRB did not give significant influence. A regression model of $97.76 \%$ is generated to predict regional revenue of Malang Raya. The conclusiongives an insight that local governments in Malang Raya should pay more attention to the effort of promoting Malang Raya to encourage tourist to come and stay longer, in order to increase the regional revenue and also to increase the share of the tourism sector to regional revenue.
\end{abstract}

Keywords: Malang Raya, regional revenue,tourism.

\section{INTRODUCTION}

Tourism has been the fastest growing sector in the world. UNWTO notes that tourism is a key to development, prosperity and well-being. As it is reported on tourism highlight 2017, Asia and the Pacific led growth in 2016. Furthermore, in South Asia, it is driven by Thailand, Vietnam, Indonesia, and Philippines. The fast growing is driven by the increase of disposable income (income after taxes). It gives more purchasing power in emerging economy market. The increased air connectivity, air capacity, more affordable travel and relaxation of visa encourage tourism demand from within and outside the region [1].

Indonesia predicts tourism export in 2019 will be the highest contributor [2]. The fast growing of tourism leads it as the core of economy in Indonesia. This is driven by the strong commitment of the tourism CEOs to develop tourism as the leading sector in the national development. The commitment is implemented in the Strategic Planning of Developing Tourism Destination and Industry in 2015 -2019 period by Indonesian Ministry of Tourism [3]. Furthermore, Indonesia's government puts tourism as a leading sector in national work-plans 2016. The national planning for developing national tourism is national plan for 2010-2025. It will develop 50 National

\footnotetext{
${ }^{*}$ Correspondence address:

Elok Tri Wahyuni

Email : elokdisparbudkotabatu@gmail.com

Address :Fac. Economics and Business, University of Brawijaya, Veteran Malang, 65145.
}

Tourism Destinations (NTD), 88 Strategic National Destination Areas (SNDA), and 222 Developing Destination Areas (DDA) [4].

East Java province has 3 NTDs, namely NTD Bromo-Malang, NTD Surabaya-Madura, and NTD Ijen-Alas Purwo. East java also have 10 SNDAs inside the NTDs. National attention to East Java shows that this province has a great opportunity in developing tourism in the regions for the resources are spread out among regions. Responding to this attention, East Java province also planned its regional tourism development by delivering the Regional Planning for Tourism Development in East Java Province 1999/20002014/2015 [5].

Malang Raya as a tourism destination has been well-known for many periods. It is no doubt that Malang Raya has been famous for the cool atmosphere in east Java. Malang Raya is one of SNDAs in the national planning for developing national tourism. It also one of a region developed by East Java in the Regional Planning for Tourism Development. Malang Raya as a region consists of Malang region, Malang municipality, and Batu municipality. Location Quotients analysis done by the province in 2009 showed 14 regions and municipalities had the economic base on tourism sector. Based on the analysis, only Malang and Batu municipalities that had economic base on tourism sector in the context of Malang Raya [6]. It is an irony that Malang regency as a larger region with the more complete destinations did not have this base. However, nowadays, Malang regency is induced to develop tourism as the leading sector in the 
economic development. It its signed by the shift of primary sector into secondary and tarsier sector as reported in the Malang Regency's regional development planning in 2016-2021.

The development of tourism in Malang Raya can be seen from the rising of tourist arrivals in this region, as shown in Figure 1. Figure 1 shows that Malang Raya has been visited by the numerous tourists during the time. The positive trend of tourist arrival in Malang Raya shows the increasing tourism demand through the time. The demand leads to increase for tourism supply. Keynes argues that total income as a function of total employment. The higher national income, so does the volume of employment work. This volume depends on effective demand. Effective demand can determine the balance of employment and income. Effective demand includes the demand of consumption and investment [7].

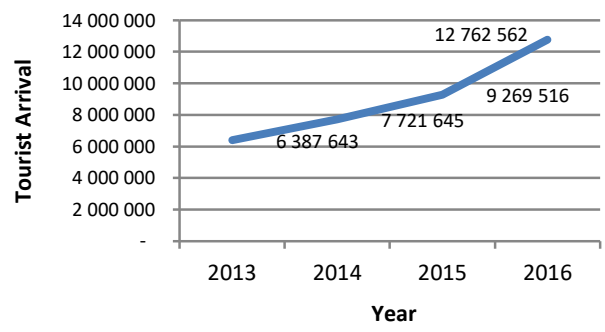

Figure 1. The Development of Tourist Arrival in Malang Raya 2013-2016. Source: Tourism Office of Malang Raya [8]

In case of tourism, effective demand can be translated into the demand of tourism product, shown by the tourism arrival, and demand of investment of private and public sector. The increasing of tourists' demands stimulates the rising of private and public investments. As a result, both national and regional and even local government will earn more income from the activities. The same opinion of Mishkin and Eakins that the main impact of tourism could be its contribution to the regional and local economy [9]. An increase number of tourist has gone hand in hand with development, rise in GDP, employment rates, rise in exports and economic activities [9]. Previous studies have also proved that the increase number of tourist gives the rise in regional revenue of DKI Jakarta [10], Gianyar region [11], and Local Governments (LGs) in Bali Province [12].

Tourism impact also gives a rise to the regional revenue of Malang Raya. It is shown by the earning of $L G$ 's revenue from optimizing local resources. Figure 2 gives the growth of regional revenue in Malang Raya. Figure 2 shows the fluctuation growth with the declining trend. It is confront the development of tourist arrival that grew significantly and also the other tourism plants' development such as hotels, restaurants, infrastructures. Pitana and Diarta said that the main contribution of tourism is through taxes [13]. Regional revenue of Malang Raya is dominated by taxes, as shown in Figure 3a. Local taxes contribute up to $60 \%$ to the regional revenue. The positive trend shows the potential of local taxes role in Malang Raya. Local taxes in tourism sector can be defined as accommodation and restaurant taxes [14]. In Indonesia, tourism taxes are hotel, restaurant and entertainment taxes. Those taxes are directly related to the fulfillment of basic tourist demand in the destination. Share of tourism taxes can be seen in Figure $3 b$. Figure $3 b$ shows the declining contribution of tourism taxes after 2010-2012, that is from $15 \%$ to $11 \%$. Next, in $2012-2014$, the contribution remains in $11 \%$, and it starts to increase in 2015 and 2016. However, the rise still can't reach the previous share. Over all, the trend of tourism taxes is declining.

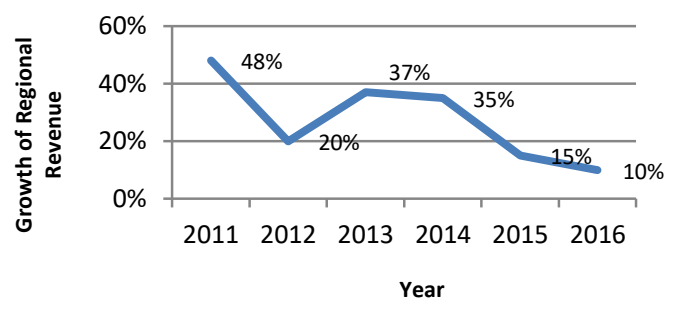

Figure 2. The Growth of PAD (Regional Revenue) in Malang Raya 2011-2016. Source: Regional Finance Bureau of Malang Raya [14].

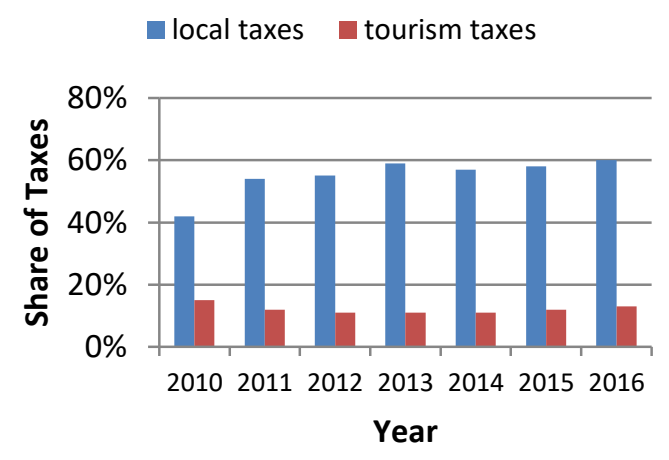

Figure 3. Share of Local Taxes and Tourism Taxes to PAD (Regional Revenue) in Malang Raya 2010-2016. Source: Regional Finance Bureau of Malang Raya [14].

It is important to study Tourism sector in Malang Raya for Tourism as a leading sector in Malang Raya. Malang Raya has the strong image of tourism that is being the concern of national 
and regional developments. The writer finds gaps in the development of tourism sector and the share of tourism sector to PAD of Malang Raya. In the right hand, the development of tourism sector, such as the development of tourist arrival, the flowered accommodation, restaurant, destination, entertainment, and also the better public and tourism facilities.However, it can't make the contribution of this sector higher than non-tourism sector. It should give the positive correlation to regional revenue. Concerning to the gaps finding, the writer eager to study how tourism sector influences regional revenue of Malang Raya.

Malang Raya has been the emerging market for tourism industry in the East Java and also in national scale. Therefore demands of more study of tourism in the development are needed to investigate. This paper attempts to provide analyses of tourism sector influencing regional revenue of Malang Raya. A set panel data from three region and municipalities during 2006-2016 is applied. Four hypotheses including five variables are tested through multiple regressions. Four variables are being considered to give significant influence on regional revenue. The variables including the number of restaurant and sum of PDRB, those did not use in the previous study. This article's contribution is its examination on the earning of regional revenue and its determinant for Malang Raya as a single destination.

\section{STUDY REVIEW}

Decentralization in Indonesia is shown in form of territorial authority of Local Governments (LGs). As a result, LGs have to manage their region in order to reach the welfare of their society [15]. Development of regional economic can be varied of each area. This is made it possible that every LG can develop their region by the potentials they have. Economic activities of region can be divided into two categories that are basis and non-basis activities. Non-basis activities are economic activities to fulfill the need of local society. While basis activities is concern as an export activities, it doesn't depend on local demand [16]. The theory of export-basis was introduced by Richardson, which mentioned that tourism is a basis sector. It can deliver income from outside the region. Furthermore, tourism is also being the engine on other sector. It can be collaborated with primary, secondary or tertiary sector in order to have a quick development. It is the same idea with the growth theory of Samuelson, i.e. turnpike theory. As it is cited in Tarigan [16], Samuelson suggested that the governments have to look at the competitive-advantage of any sectors they have in their region. The sector is important to create or fuel other sector to a fast development. Tourism sector, thus, can afford both theories.

According to Tribe [17], tourism is an activity in visiting for at least one night for leisure and holiday, business and professional or other tourism purposes. Visiting means a temporary movement to destinations outside the normal home and workplace. The visiting can be in group or individual [18]. Tourism is an activity engaged in by people who travel [19]. The traveler is called as tourist. Tourism activities include the guest and the host. The guest can be domestic tourist and international tourist. The host can be local people, local government, or private sector. Both also show the demand and supply side of tourism. Tourists demand tourism product to fulfill their need, want and hope. Tourism product is not a single product. It is a combination of many products both tangible and intangible that are bonded into tourism package. Tourism product, then, is produced by tourism industries. The industry also called tourism enterprises [18], travel industry and hospitality industry. Tourism industry has three travel plant, they are transportation, accommodation, food and beverage industries, and hospitality industry [20]. There are some important elements of tourism industry [21]. They are attractions, facilities, infrastructures, transportations, and hospitality. Tourism destination must have attractions. The tourist destination must have something to do, to see and to buy [22]. The tourist will experience through the travel by doing, seeing and buying something in the destination. The whole experience will lodge in their mind in form of memorable ones. Then, the activities of tourist will lead to the economic activity of the host.

Today, the host of destination made tourism to be the leading sector, the key of economy and also the core economy of some countries, such as Indonesia. It is the fact that tourism sector can be used as development tool. Since tourism resources are owned by the region, the development of tourism will give great impact to the regional and local economy. The impact will be the rise in GDP, employment rates, rise in exports and other economic activities [9]. Besides that, Tribe [17] also adds that tourism can lead to the prosperity. Tourism has become a 
major source of economic diversification for many countries. It gives effective backward and forward linkages with the rest of the economy, allowing new employment and income earning opportunities [22,23]. The income earning opportunities are both for government, local people and private sector. LG have the benefit of regional income through taxation. Local taxes in tourism sector are hotel taxes, restaurant taxes, and entertainment taxes.

Regional revenue and tourism sector have been examined from varies perspective, including financial data and tourism statistics. Most of studies proposed a multiple regression and develop it into a path analyses. Tourist arrival is being the main indicator of gaining income. Hotel room occupancy rate is also indicating the development of tourism and reflects the potential of local governments' revenue. Since, restaurant industry is also play important part in tourism, the number of restaurant also consider in the study for its role in the gaining of the revenue. This paper also use sum of PDRB(Gross Regional Domestic Product), by the reason that tourism sector also supported by all sectors in PDRB.

\section{RESEARCH METHOD}

Economic models are built to describe relationships between economic variables and predict the effects of changing these variables [17]. Models are generally simplified abstractions of the real world. They have two key components. First assumptions are made which build the foundations for the model. Second implications or outcomes are predicted by the working of the model. As the channel crossing becomes a more competitive environment, since the opening of the tunnel, the predictions of competition theory can be tested empirically, or in other words by making observations. The term ceteris paribus is often used in economic analysis, meaning all other things remaining unchanged. This is important because in the real world several factors often occur at the same time, some exaggerates a particular effect, and some countering it.

This research is done in Malang Raya. They are Malang municipality, Batu municipality, and Malang region. The data used are secondary data. They are LGs' regional revenues, the number of tourist arrivals, hotel's room occupancy rate, the number of restaurant, and sum of PDRB (Gross Regional Domestic Product)in 2006-2016. Source of data are from finance bureau, tourism office, region statistic bureau, and other governments' reports in Malang Raya.

The method is quantitative approach by using panel data regression. It is used to identify the causal relationship between variables [24]. This research used the log-linear form of each variable to show the elasticity of them [25] or to get direct estimation of variables elasticity [24]. The log-linear model can predicted the partial elasticity of dependent variable (Y) towards independent variable $(X)$ in the assumption of ceteris paribus. It shows every percentage change of Y's as the change of the percentage of $X$. the general model will be as follow:

$$
\mathrm{Ln} \mathrm{Y}_{\mathrm{it}}=\alpha+\mathrm{b}_{1} \ln \mathrm{X}_{1 \mathrm{it}}+\mathrm{b}_{2} \ln \mathrm{X}_{2 \mathrm{it}}+\mathrm{b}_{3} \ln \mathrm{X}_{3 \mathrm{it}}+\mathrm{b}_{4} \ln \mathrm{X}_{4 \mathrm{it}}+\varepsilon
$$

\section{Description:}

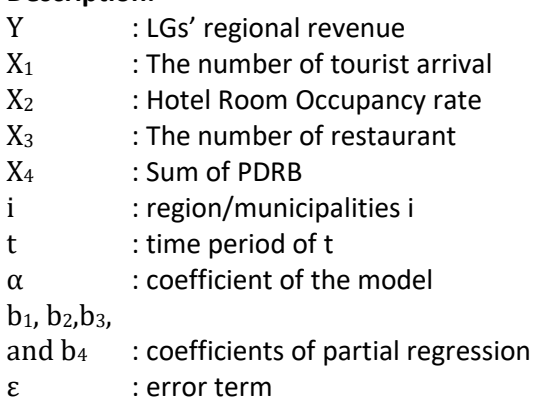

The data is estimated by using fixed effect model. Next, the simulant, partial and also $\mathrm{R}^{2}$ test are done by $p$-value concept. The $p$-value used is $5 \%$. Finally, the classical assumption tests are heteroscedasticity and multicollinearity. Hypotheses of this research are:

1. Tourism sector (the number of tourist arrival, hotel's room occupancy rate, the number of restaurant, and sum of PDRB) has significant influence on regional revenue

2. The number of tourist arrival has significant influence on regional revenue

3. Hotel's room occupancy rate has significant influence on regional revenue

4. The number of restaurant has significant influence on regional revenue

5. Sum of PDRB (Gross Regional Domestic Product)has significant influence on regional revenue

\section{RESULT AND DISCUSSION}

Malang Raya is a region in East Java consists of three local governments (LGs). They are Malang municipality, Batu municipality, and Malang region. Both municipalities are the development LG of Malang region, so they are bounded by the region, both territorially and 
historically. The region is a mountainous one. It is famous for its cool air. It also has many water resources, rivers, and beaches. The soil is fertile, so Malang Raya is fit in agriculture activities. The abundant resources are also the capital for developing tourism sector. As shown in the $L Q$ analysis by using PDRB 2011-2015, the basis sector of Malang Raya are in the agriculture, forestry and fishing; manufacturing; water supply, sewerage, and waste management and remediation activities; wholesale and retail trade, repair of motor vehicles and motorcycles; accommodation and food service activities; information and communication; financial and insurance activities; real estate; public administration and defense, compulsory social security; education; human wealth and social work activities; and other services activities.

Malang Raya as a single destination is determined by the regional tourism development plan of East Java. According to the plan, Malang Raya is a center of accommodation services, center of culture and sea attraction, center of natural attraction of mountainous area and center of convention venue [26]. Malang Raya is also the one of main services city. It has the role as the main gate and center of many activities, also its strategic role in the development of other regions [5]. Malang Raya has already famous as a tourism destination for it abundant tourism attractions. It has natural, cultural, and manmade tourist attraction. Malang Raya is easy to reach by air, road or water transportation. Malang Raya has an airport, bus station, and railway station as the main gate of tourist arrivals. It also supported by the number of accommodation and food services, that are claimed to be the most stared hotels in East Java [27]. Malang people are various ethnicities. However, they can live together in peace. They have their hospitality to every new people coming, including tourists. Those are potential of Malang Raya as a tourist destination.

Tourist arrival in Malang Raya contributes to the gain of regional revenue via entertainment tax, hotel tax and restaurant tax. The growth of entertainment tax is sharply fluctuating (Fig. 4). However, the number of tourist and also the new destination and event are flowering through the time. It indicates there are tax leakages. Share of entertainment tax shows gradual decreasing in the development of tourism sector in Malang Raya (Fig. 5). This may be caused by the gain from other new local taxes in regional revenue.

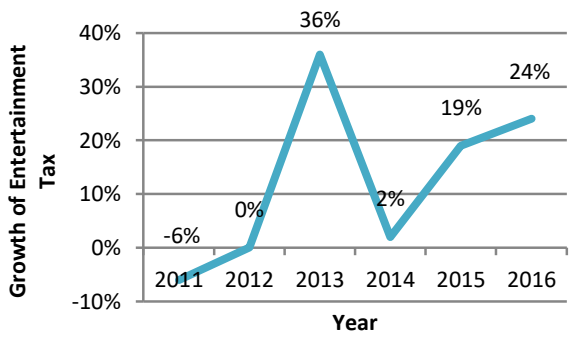

Figure 4. Growth of Entertainment Tax of Malang Raya 2011-2016. Source: Regional Finance Bureau of Malang Raya [14].

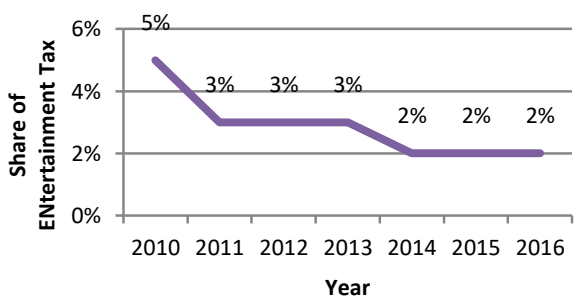

Figure 5. Share of Entertainment Tax of Malang Raya 2010-2016. Source: Regional Finance Bureau of Malang Raya [14].

The growth of hotel tax is also sharply fluctuating with the decreasing trend (Fig. 6). However, on the other side, the accommodation business is flourishing through the region. This can indicate that the effort in tax collection needs more improvement. On the other side, the share of hotel tax is good (Fig. 7). It keeps giving a constant share in the last three years.

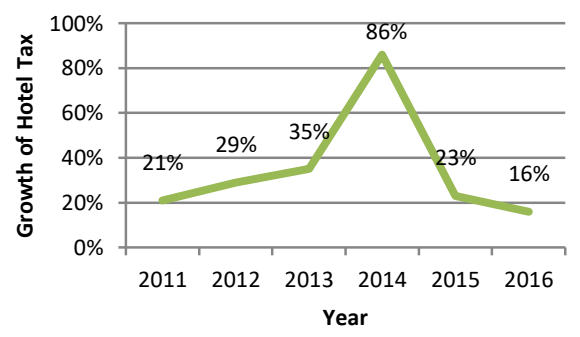

Figure 6. Growth of Hotel Tax of Malang Raya 2011-2016. Source: Regional Finance Bureau of Malang Raya [14].

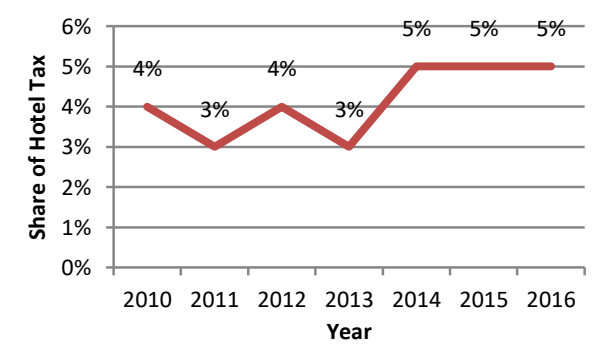

Figure 7. Share of Hotel Tax of Malang Raya 2010-2016. Source: Regional Finance Bureau of Malang Raya [14].

The growth of restaurant tax is fluctuating every year (Fig. 8). However, it gives an 
increasing trend. This tax is very potential to be developed. Share of restaurant tax is smoothly fluctuating. A constant share of $5 \%$ is on the last two years (Fig. 9).

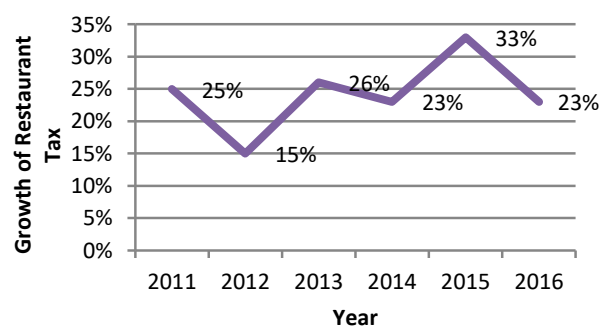

Figure 8. Growth of Restaurant Tax of Malang Raya 20112016. Source: Regional Finance Bureau of Malang Raya [14].

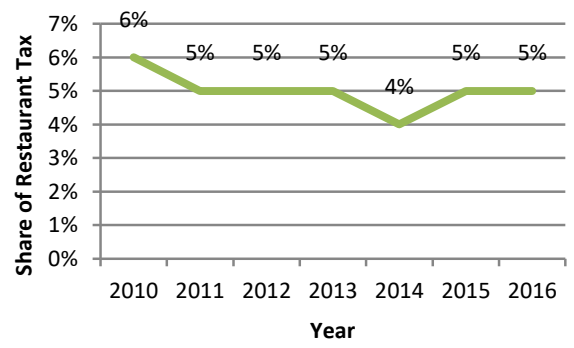

Figure 9. Share of Restaurant Tax of Malang Raya 20102016. Source: Regional Finance Bureau of Malang Raya [14].

\section{Model Analysis}

Result of data analysis using fixed effect model is resumed in Table 1 . Table 1 show that simultaneously all independent variables are giving significant influence on regional revenue. It is showed by the Probability of F-statistic is smaller than 5\% (0.05), that is 0.00 . Partially, there are two significant variables influencing regional revenue. They are tourist arrivals and hotel's room occupancy rate. Both have probabilities 0.00 , smaller than $p$-value $5 \%$. The other two variables, they are the number of restaurant and sum of PDRB do not giving a significant influence. Since both probabilities are bigger than $5 \%$, they are 0.14 for the number of restaurant and 0.056 for sum of PDRB. The fitness of the model can be seen from the value of R-squared. The result shows that R-squared value is 0.9776 . It means that $97.76 \%$ dependent variable can be explain by the independent variables/predictor in the model.

Classical assumption test as the requirement of regression analysis in this research are heteroscedasticity and multicollinearity tests. Heteroscedasticity test uses Glesjer test, by regressing the independent variables with residual absolute. If their $p$-value is bigger than $5 \%$, so it is free from heteroscedasticity problem.

Table 2 showed the $p$-value of each predictor is bigger than 5\%, so it is free from heteroscedasticity problem. Next, multicollinearity test uses correlation matrix as shown in Table 3. The result shows that there is no strong correlation between variables, so it is free from the multicollinearity problem.

Table 1. Resume of Fixed Effect Model

\begin{tabular}{lcccc}
\hline \multicolumn{1}{c}{ Variable } & Coefficient & Std. Error & t-Statistic & Prob. \\
\hline C & 1973.011 & 4.472340 & 441.1584 & 0.0000 \\
Number of tourist arrival & 3.535095 & 0.229148 & 15.42713 & 0.0000 \\
Hotel room Occupancy rate & 1.478129 & 0.394086 & 3.750780 & 0.0009 \\
Number of restaurant & 0.637009 & 0.420109 & 1.516294 & 0.1415 \\
Sum of PDRB & -0.404274 & 0.202307 & -1.998315 & 0.0562 \\
\hline R-squared & $\mathbf{0 . 9 7 7 6 1 8}$ & & & \\
F-statistic & 189.2751 & & & \\
Prob(F-statistic) & 0.000000 & & & \\
\hline
\end{tabular}

Source: Data Analysis, 2017.

Table 2. Resume of Glesjer Test

\begin{tabular}{lcccc}
\hline \multicolumn{1}{c}{ Variable } & Coefficient & Std. Error & t-Statistic & Prob. \\
\hline C & $1.66 \mathrm{E}+10$ & $1.62 \mathrm{E}+10$ & 1.020970 & 0.3167 \\
Number of tourist arrival & -7790.529 & 6326.991 & -1.231317 & 0.2292 \\
Hotel room occupancy rate & -1888233. & 40670377 & -0.046428 & 0.9633 \\
Number of restaurant & -11658139 & $4.81 \mathrm{E}+08$ & -0.024258 & 0.9808 \\
Sum of PDRB & 1118389. & 459362.5 & 2.434654 & 0.0221 \\
\hline
\end{tabular}

Source: Data Analysis, 2017. 
The Influence of Tourism on Regional Revenue of Malang Raya

(Wahyuni et al.)

Table 3. Correlation Matrix

\begin{tabular}{ccccc}
\hline & $\begin{array}{c}\text { Number of tourist } \\
\text { arrival }\end{array}$ & $\begin{array}{c}\text { Number of } \\
\text { restaurant }\end{array}$ & $\begin{array}{c}\text { Hotel room } \\
\text { Occupancy rate }\end{array}$ & Sum of PDRB \\
\hline Number of tourist arrival & 1.000000 & 0.359207 & 0.851703 & 0.290663 \\
Number of restaurant & 0.359207 & 1.000000 & 0.422142 & 0.206617 \\
Hotel room occupancy rate & 0.851703 & 0.422142 & 1.000000 & 0.478487 \\
Sum of PDRB & 0.290663 & 0.206617 & 0.478487 & 1.000000 \\
\hline
\end{tabular}

Source: Data Analysis, 2017.

\section{Discussion}

The model created based on the fixed effect is

$Y=1973.011+3.535 X_{1}+1.478 X_{2}+0.637 X_{3}-0.404 X_{4}$

As the log-linear model can give the elasticity of $Y$ to the change of $X$, the model can be interpreted as the following. First, coefficient of $X_{1}$ is 3.535. It means that every percent the increase in tourist arrival can give the increase in regional revenue for 3.535 percent ceteris paribus. Second, coefficient of $X_{2}$ is 1.478 . It means that every percent the increase in hotel's room occupancy rate can give the increase in regional revenue for $1.478 \%$ ceteris paribus. Third, coefficient of $X_{3}$ is 0.637 . It means that every percent the increase in the number of restaurant can give the increase in regional revenue for $0.637 \%$ ceteris paribus. The last, coefficient of $X_{4}$ is -0.404 . It means that every percent the increase in sum of PDRB will decrease regional revenue for $0.637 \%$ ceteris paribus.

\section{The Influence of Number of Tourist Arrival}

The significant influence of tourist arrival is consistent with Keynes theory that national income in line with consumption. It is also strengthened Wahab's opinion that tourist arrival and tourist consumption also contribute to the gain of local and regional government [28]. Since tourists are mostly not local people, their expenditure is categorized as an export gain for LGs. This is fitted the basis export theory by Richardson [29], that tourism is a basis activity because it can give income from other region; supported by otherstudies that in line with the result $[10,11,12,30]$. They found that tourist expenditure had been the income for government through taxation. However, the result is contradictive with several studies which found that tourist arrival is small because of the lack of promotion, bad facilities, and safety factor [31,32,33].

The significant influence of tourist arrival can be affected by some facts, both in demand and supply point of view. The demand side reflects the need of tourist in conducting their travel. It is usually influenced by some factors, such as income, other prices, comparative quality or value added, fashion and tastes, advertising, opportunities for consumption, population, and other factors [17]. First, the increase of income makes people have more money to save and spend in leisure. Second, supplies of tourism products in Malang Raya are varied, so a competitive price of tourism package gives more choice for tourist. Third, tourist also compares the quality or value added in the package as they need to get. Forth, fashion and taste reflect the tourist behavior. It is usually influenced by culture, social status, personal characteristic and psychological aspects [19].

Keeping the relationship among families is being a culture in the society. The sense of ethnicity motivates the traveller to visit friend and relatives, go back to homeland, plus do other tourism activities. Personal characteristics such as age, occupation, lifestyle, personality, etc. affect the choice of doing leisure. For instance, the higher education of the society will increase the motivation to travel in order to have more experience and advance knowledge. Modern work activities identified as hard working activities, so the need of incentive travel is increase. While some professions need to travel as the activities, such as business man, civil servant duties, news reporter, etc.

Fifth, mass advertising of tourism destination lead more tourist to come. It also supported by the development of 4T (technology, transportation, trade and tourism). It gives more chance in wide range of promotion effort, promotes low cost carrier, and brings mass tourist. Sixth, opportunities for consumption can be seen from the increase of leisure time and human health condition. For instance, public policy in giving 5 days' school as well as 5 days' work beside the national holiday that has been scheduled give more chances to travel. The increase of human health condition, especially for pension, creates more travel in their leisure time. Seventh, the increase of population leads to migration. The 
memories in the homeland and work land usually call back people to revisit. Finally, other factor, such implementation of school program in learning by doing and fun learning that is combined into education-tourism package led the student learning activities through tourism activities.

The supply side of tourism in Malang Raya can be seen from the development of tourism attraction, the flowered accommodation and restaurants, the better public facilities, transportation, and the hospitality of local people. Those developments attract more tourists to come. Various attractions, accommodation, transportation in various prices give them more choices to buy tourism package.

\section{The Influence of Hotel Room Occupancy Rate}

The significant influence of hotel occupancy rate support Wahab's view that tourist length of stay gives more income for local and regional government [28], in line with the other studies $[12,34]$. The significant influence of hotel occupancy rate can be identified as some facts. Tourists need accommodation to stay more days. Accommodation is a primary industry in tourism [18]. As a primary industry, it gives a primary contribution to hotel taxes for the LGs. Since, hotels are in the supply side, they are in line with the demand of tourist. Promotion effort of both the hotels owners and government creates more demands. Hotels can give interesting package for all segments of tourist. Hotels also cooperate with government and private sector in conducting regional, national and international events and festivals. The increase of MICE (Meeting, Incentive Convention, and Exhibition) activities holds by private and public organization also needs hotels and their facilities as the venue.

\section{The Influence of the Number of Restaurant}

Restaurant is a vital travel plant [20]. The important of restaurant in tourism also assessed by several studies [35-42]. However, there are no studies including the number of restaurant analyses to regional income. Here is the different of this study. The insignificant role of number of restaurant can be affected by some facts. First, culinary is developed into tourism attraction as a gastronomic product. Gastronomic product can attract tourist as in Bandung [42], Nordic countries [39] and other gastronomic destinations including Malang Raya. However, the rapid growing of these businesses doesn't follow by the collecting of the data. So the basis data for the taxes can't be fulfilled. Second, the increase of foodies' traveller attracted on local traditional food. They eager to know local food, local receipt, cooked and eat locally with local people. This is of course can't contribute to LGs' revenue. Third, tourist motivation in visiting friend and relatives leads their relative serve their food and they don't go to restaurant. Fourth, the flourish of local street-food, local food-truck, small food services conducting by individual and household as the effect of the new opportunity in job creation and also high demand on food services doesn't contribute to LGs' revenue through restaurant taxes. Fifth, hotel giving all in package for its guest only give impact to the hotel taxes, not to the restaurant taxes.

\section{The Influence of Sum of PDRB}

At last, the insignificant PDRB of Malang Raya gives the insight that PDRB as a representation of total goods and services produced by the society, doesn't give a direct contribution to the tourism product that have role in regional revenue. It is fit the growth theory of Samuelson that is turnpike theory. Tourism sector is being the engine and fuelling other sectors to develop. As a result, the productivity of other sectors increases along with the development of tourism sector. A study found that PDRB can't contribute to LGs' revenue if tourists don't consume good food and services as a tourism product [32]. This could be the same condition as the result of this study. However it is contradictive with the previous studies that found PDRB can reflect the LGs revenue $[30,31,43]$.

\section{Implication of the Study}

The growth of entertainment tax that sharply fluctuated and it decreasing share after 2010 are not in line with the result of this analyses that the number of tourist arrival give a significant influence on regional revenue. It is needed efforts to stabilize and continuously increasing the gain of entertainment taxes by optimizing the collection of the taxes. Next, the growth of hotel tax is fluctuating with the decreasing trend contradictive with the increasing share and significant influence of hotel room occupancy rate on regional revenue. These shows there are more potential of gaining hotel tax to be optimized. Meanwhile, the growth of restaurant tax is smooth fluctuating with the constant trend in line with the insignificant influence of the number of restaurant on regional revenue. However, it is also a potential one to be developed and optimized. 


\section{CONCLUSION}

Malang Raya has a numerous potential as a destination. It has abundant of tourism resources such as nature, culture, and people. Those can attract tourists to visit. The tourist arrival in Malang raya gives a significant sign that they are very important in increasing regional revenue. The more tourists come, the more income for the region. Beside the tourist arrival, hotel's room occupancy rate also gives the significant role in determining regional revenue. Occupancy rate of hotels can show tourists' length of stay. Not only gives impact on hotel taxes, they also may take the role for other source of regional revenue. Since, the tourist also need food services, it should be also give a significant one. However, in this research, the number of restaurant still can't be one of variables that can predict the gain of regional revenue. It may be caused by not all tourist go to restaurant in their vacation. The sum of PDRB usually show the development of tourism sector through the productivity of region. However, not all products can give their direct contribution to the tourism product that have role in regional revenue. Based on the finding, governments in Malang Raya are expected to pay more attention to the effort of promoting Malang Raya to encourage tourist to come and stay longer in order to increase and giving more shares on regional revenue.

\section{REFERENCES}

[1] UNWTO. 2017. UNWTO tourism highlights 2017. World Tourism Organization. Madrid.

[2] Indonesian Ministry of Tourism. 2017. CEO message \#18: tourism as the core of state economy. Ministry of Tourism. Jakarta.

[3] Indonesian Ministry of Tourism. 2015. Strategic planning of destination and industry of tourism2015-2019. Ministry of Tourism. Jakarta.

[4] Government of Republic of Indonesia. 2011. Supplementary I Government Regulation of Republic of Indonesia No. 50 year 2011 about main planning of national tourism development 2010 - 2025, target of national tourism development 2010-2025. Government of Republic of Indonesia, Jakarta.

[5] Provincial Government of East Java. 1998. Provincial Regulation of $1^{\text {st }}$ Level Regional of East Java No. 16 year 1998 aboutmain planning of $1^{\text {st }}$ level regional tourism development East Java 1999/2000 -
2014/2015. Provincial Government of East Java, Surabaya. 1-24.

[6] Afandi, A. 2014. Analisis tourism livelihoods berkelanjutan di Kota Batu: Pendekatan SLFT (Sustainable Livelihoods Framework For Tourism). Thesis. University of Brawijaya. Malang.

[7] Adisasmita, R. 2013. Teori-teori pembangunan ekonomi dan pertumbuhan wilayah, $1^{\text {st }}$ Ed. Graha Ilmu. Yogyakarta.

[8] Tourism Office of Malang Raya. 2017. Tourist arrival in Malang. Tourism Office of Malang Raya. Malang.

[9] Osmankovic, J., R. Zrnic and V. Kenjic. 2010. Tourism-creator of the local and regional development. International Conference ICES 387, 1-15.

[10] Arlina, R. and E. Y. Purwanti. 2013. Analisis penerimaan daerah dari industri pariwisata di Provinsi DKI Jakarta dan faktor-faktor yang mempengaruhinya. Diponegoro Journal of Economics 2(3),1-14.

[11] Pertiwi, N. L. G. A. 2014. Pengaruh kunjungan wisatawan, retribusi obyek wisata dan PHR terhadap PAD Kabupaten Gianyar. E-Jurnal Ekonomi Pembangunan 3(3), 115-123.

[12] Suastika, I. G. Y. and I. N. M. Yasa. 2015. Pengaruh jumlah kunjungan wisatawan, lama tinggal wisatawan dan tingkat hunian hotel terhadap Pendapatan Asli Daerah dan kesejahteraan masyarakat pada Kabupaten/Kota di Provinsi Bali. E-Jurnal Ekonomi Pembangunan 6(7), 1332-1362.

[13] Pitana, I. G. and I. K. S. Diarta.2009. Pengantar ilmu pariwisata. Penerbit Andi. Yogyakarta.

[14] Regional Finance Bureau of Malang Raya. 2017. The growth of regional revenue 20112016. Regional Finance Bureau of Malang Raya. Malang.

[15] Sabarno, H. 2008. Untaian pemikiran otonomi daerah: memandu otonomi daerah menjaga kesatuan bangsa. Sinar Grafika. Jakarta.

[16] Tarigan, R. 2014. Ekonomi regional: teori dan aplikasi, revisi. Bumi Aksara. Jakarta.

[17] Tribe, J. 2004. The economics of recreation, leisure and tourism, $3^{\text {rd }}$ Ed. Elsevier. Oxford.

[18] Yoeti, O. 1982. Pengantar ilmu pariwisata. Angkasa.Bandung.

[19] Tan, A., Tse, E.C.Y. and C. L. Wong. 2009. Hospitality marketing. Education Bureau. Hongkong. 
[20] Pendit, N. S. 1994. Ilmu pariwisata sebuah pengantar perdana. Pradnya Paramita. Jakarta.

[21] Spillane, J. J. 1989. Ekonomi pariwisata: sejarah dan prospeknya. Kanisius. Yogyakarta.

[22] Bambang and Sunaryo. 2013. Kebijakan pembangunan destinasi pariwisata: konsep dan aplikasinya di Indonesia. Gava Media. Yogyakarta.

[23] Ojo, J. S. 2014. Managing tourism for socioeconomic development in Nigerian Local Government : a case study of Idanre Local Government. Journal of African Studies Development 6(February), 29-35.

[24] Lagos, D. G. 1999. Exploratory forecasting methodologies for tourism demand. Ekistic, 394-396.

[25] Gujarati, D. N. 2007. Dasar-dasar ekonometrika Vol 1, $3^{\text {rd }}$ Ed. Erlangga. Jakarta.

[26] Malang City Government. 2005.Pemerintah RPJPD Kota Malang Tahun 2005-2025. Malang City Government, Malang. 1-116.

[27] Statistic Bureau of Batu City. 2016. Statistik perhotelan Kota Batu tahun 2016. Statistic Bureau of Batu City, Batu.

[28] Wahab, S. 1992. Pemasaran pariwisata. Pradnya Paramita.Jakarta.

[29] Richardson, R. B. 2010. The contribution of tourism to economic growth and food security. Food Security Collaborative Working Papers 97140, Department of Agricultural, Food, and Resource Economics, Michigan State University, East Lansing.

[30] Dewi, A.A I. A. D. S. and I. K. G. Bendesa. 2013. Analisis pengaruh jumlah kunjungan wisatawan, dan produk domestik regional bruto terhadap Pendapatan Asli Daerah Kabupaten Gianyar. E-Jurnal Ekonomi Pembangunan 5(2), 260-275.

[31] Jaya, G. B. P. and A. B. P. Widanta. 2014. Analisis faktor-faktor yang berpengaruh terhadap Pendapatan Asli Daerah (PAD) Kota Denpasar. E-Jurnal Ekonomi Pembangunan 3(5), 201-208.

[32] Fariantin, E. and S. Amri. 2017. Analisis pengaruh sektor pariwisata dan PDRB (non migas-non pertanian) terhadap peningkatan PAD di Kabupaten Lombok Utara. Jurnal Valid 14(1), 46-52.

[33] Widyaningsih, P. and M. K. S. Budhi. 2014. Pengaruh jumlah kunjungan wisatawan terhadap penerimaan pajak hotel, pajak restoran dan Pendapatan Asli Daerah. E-
Jurnal Ekonomi Pem-bangunan 3(4), 155163.

[34] Hascaryo, D. L., S. Subanti and Pangadi. 2013. Pengaruh jumlah kunjungan wisatawan dan tingkat hunian hotel terhadap Pendapatan Asli Daerah berdasarkan kota di Provinsi Jawa Tengah dengan pendekatan Fixed Effect Model. Thesis. Department of Mathematics, Sebelas Maret University. Surakarta. 18.

[35] Alatorre, M. M. 2016. Edible identities: food as cultural heritage. Journal of Heritage Tourism 11(2), 191-192.

[36] Alderighi, M., C. Bianchi and E. Lorenzini. 2016. The impact of local food specialities on the decision to (re)visit a tourist destination: Market-expanding or businessstealing?. Tourism Management 57, 323333.

[37] Di Matteo, D. and G. Cavuta. 2015. Enogastronomic tourism: can it mitigate the intangibility of the destination? streetfood as a new business model for the management of tourist regions. Procedia Economics and Finance 39(November), 347356.

[38] Lan, L. W., W. W. Wu and Y. T. Lee. 2012. Promoting food tourism with Kansei cuisine design. Procedia - Social Behavioural Sciences 40(March), 609-615.

[39] Lund, T. B., U. Kjærnes and L. Holm.2017. Eating out in four Nordic countries: National patterns and social stratification. Appetite 119, 23-33.

[40] Santeramo, F. G., A. Seccia and G. Nardone. 2017. The synergies of the Italian wine and tourism sectors. Wine Economics and Policy 6(1), 71-74.

[41] Yusoff, N. M. M., S. M. Zahari, M. Z. M. Kutut and M. S. M. Sharif. 2013.Is Malaysian food important to local tour operators?. Procedia - Social Behavioural Sciences 105, 458-465.

[42] Astuti, S. and H. Hanan. 2012. The behaviour of consumer society in consuming food at restaurants and cafes. Procedia - Social Behavioural Sciences 42(July), 429-435.

[43] Sari, P. L. P. 2011. Analisis variabel-variabel yang mempengaruhi Pendapatan Asli Daerah (PAD) Provinsi Bali. Jurnal Ilmiah Akuntansi dan Humanika 2(2), 715-737. 